know the complex and therefore delusive and often apparently contradictory character of the phenomena resulting from lesions of the brain, but I think the weight of experimental evidence (and surely this is more reliable than pathological) is the other way. Experiments on pigeons and dogs ("Dalton's Physiology," pp. 430 and 454) seem to show that lesions of the brain affect the opposite eye as well as the opposite side of the body. Anatomical structure also would lead as to expect this, for the fibres of the optic tracts cross over in the chiasma, in birds completely, and in mammals largely. But even if it were otherwise, I do not see that the question is materially affected. If right-sidedness is inherited, there must be, or must have been, some advantage in it; and there is no reason why inheritance should not have affected different sides of the brain for hand and for eye, if such were necessary to bring about the result.

Again, Mr. Wharton has the singular idea that because Europeans, who are a right-handed people, write from left to right, therefore Eastern nations who write from right to left must be left-handed! Obviously this does not follow. Many righthanded motions, such for example, as striking with a whip are from right to left, so that the contrary stroke, on account of its unfrequency, is called backhanded.

Lastly, Mr. Wharton alludes to the rules of boxing. The left hand is used mostly for striking, and the right for guarding. It would be well if some one acquainted with the subject would give us its history. My impression is that the present practice is comparatively recent, perhaps forty to fifty years old, and that formerly the right hand was used mostly for striking, and the left for guarding. I think, further, that even now the left is used more for feints and lighter blows, while the right is reserved for favourable opportunities to plant decisive blows.

Berkeley, Cal., April 23

JOSEPH LE CONTE

\section{Dark Transit of Jupiter's First Satellite}

ON May 18 , at $8 \mathrm{~h}$., on observing Jupiter with my Io-inch reflector, p. 252, I saw three very dark spots-one near the planet's centre, and two others not far advanced upon the east limb. These I took to be the shadows of satellites, and on reference found that the shadows of Satellites I. and II. were really upon the planet; also Satellite I. itself. The latter was evidently the spot near the centre of the disk, and it appeared almost equally as black as the shadow. The satellite was situated close to the equatorial white spot, and in point of fact was projected upon the north-east borders of that object. The latter was estimated on the central meridian at $8 \mathrm{~h} .5 \mathrm{~m}$., so that its longitude, computed on the diurnal rate of $878^{\circ} .46 \quad(=$ rotation of 9 h. 5 om. $7^{\circ} 42 \mathrm{~s}$.), was $94^{\circ} \cdot 3$.

When near mid-transit, Satellite I., as regards its visible aspect, could hardly have been distinguished from its shadow, and I believe the very dark appearance of the satellite on this occasion to have been somewhat exceptional ; for though I have observed a considerable number of its transits, I never saw it nearly so dark before.

W. F. DENNING

Bristol, May 19

\section{The Remarkable Sunsets}

A COPY of NATURE (vol. xxix. p. 149) just received here contains an article on "Remarkable Sunsets" which were scen in all parts of the world during the latter days of November and the early days of December. It may interest your readers to know that precisely similar sunsets to those described in the papex referred to above occurred here for several days in December. The "rosy pink after-glow" immediately succeeded the sunset, and lasted from ten to fifteen minutes. The phenomenon considerably scared the Chinese, who feared it portended some evil to the Emperor. The winter has been remarkably mild and dry; the first fall of snow, a very heavy one, took place on March I. This region is volcanic; we have occasional shocks of earthquake.

T'ai Ynen Fu,eShansi, North China, March 5

\section{"Notes on Earthworms"}

ReFERriNg to Mr. Hughes' communication to NATURE of May 15, p. 57, I myself to-day saw a small worm pursued by a black insect, also evidently the larva of one of the Carabidæ. I was attracted by observing the worm emerge from the ground and hurry quickly away. When about five inches from its burrow the larra came out of the same burrow, and briskly followed in a zigzag course, until it overtook its prey, which it then seized near the tail end and dragged under some loose earth. No doubt the worm had been pursued mderground, and was endeavouring to make its escape.

224, Camberwell New Road, May I 7

\section{The Recent Earthquake}

IN p. 57 of the last number of NATURE notice is taken of the lack of observation on the late earthquake in Central Kent, Surrey, or Sussex. In Tonbridge we have known of three instances in which it was certainly felt. On the morning of April 22 a lady in bed in a room on the first floor felt a push from the foot of the bed so strong that she asked her little girl, who was in the room, why she was shaking it so, which of course the child denied - the bedstead being of iron and too heavy for her to have moved; the vallance at the head of the bed swayed to and fro. The second instance we heard of was an Indian officer, who felt it, while standing leaning against his mantelpiece, directed about from north-north-east to south-south-west. The third instance was an invalid lady in bed on the first floor.

$$
\text { 22, Hadlow Road, Tonbridge, Kent, May } 19
$$$$
\text { M. I. PI.ARR }
$$

\section{Animal Intelligence}

ONE night a loud knock was heard at the back door, and as the door could not be reached by any one outside the house except by getting over the garden wall, some alarm was caused. On the knock being impatiently repeated, the door was opened, and the cat ("Mrs. Muffins") walked in with great dignity. Since then she has never failed to make known her presence in the same way, always waiting after the first knock. Some weeks elapsed before it was ascertained how the knocking was produced, but at length it was discovered that a slip of wocd which runs down the side of the door was loose at the bottom; this slip she pulls out with her paw, and then allows it to rebound. She is a very affectionate mother. Some time ago her mistress, by accident, hurt her kitten. "Mrs. Muffins" walked up to her and gave her two or three sharp slaps on the dress. To-day the same thing has occurred; but on this occasion, as the servant was the offender, "Mrs. Muffins" followed her into the kitchen to chastise her. I may also add that she has shown great intelligence in making her wants known to her friends.

E. A. LONERGAN

\section{AGRICULTURE IN THE UNTTED STATES}

WE may learn many a good lesson by observing the admirable manner in which the various Boards of Agriculture discharge their duties in the United States. With a sound discretion the mutual influences of geology and agricultural practice are prudently considered in association with the investigations of the chemist and the records of the Census Office. In these respects the various States are greatly in advance of anything provided in the United Kingdom. We have our Geological Survey most carefully conducted, and the maps showing the solid geology of the country are excellent. In addition to these we have another series of geological maps showing the drifts covering up these rocks, but at this point we cease to follow the example set us in the United States. Aided as each individual State is by a series of experts, such as the State Botanist, the State Geologist, the State Entomologist, the State Chemist, and similar officials, we thereby find most valuable help rendered to the agriculture of the country. This assistance is rendered more effective by reason of the concerted action by which it is so generally characterised. Each scientist views any given subject from his own special standpoint, and the great advantage of concerted action is the more mellowed judgment which is thereby secured.

In the Report before us we have one of those happy blendings of science and practice which is so well calcuI "Geological Survey of Alabama, embracing an Account cf the Agricul- 